\title{
Some Remarkable Amulets in Ancient Egyptian Art
}

Doha Mohamed Sami Abdel-Hamid

Higher institute of Tourism, Hotels and Computer - El-Seyouf, Alexandria.

\begin{abstract}
An "Amulet" is a small object to be worn on the living or dead body to protect the bearer against specific dangers and to provide him with special characteristics, such as health, strength or fierceness. Amulets were often in the shape of animals, plants, sacred objects, or hieroglyphic symbols, natural or manmade objects, the commonest of all is faience. The power and effectiveness of a natural amulet might derive from its shape, its material, its color, and its scarcity, or any combination of these properties. Amulets were made of different kinds of stone like lapis lazuli, carnelian, red or green jasper, hematite, steatite, beryl, serpentine, gold and limestone. Manmade amulets include pendants in the form of deities, demons, animals, plants, parts of the human body, furniture, tools and ritual objects. Some of these amulets are simply miniature models of things which the deceased needed or desired in the afterlife. A distinction is sometimes made between amulets and talismans; the purpose of an amulet is to protect, while the purpose of a talisman is to enhance a quality in the wearer or to promote success. The potency of amulets was recognized in the religious ceremonies and rituals especially those relating to funerary and mortuary rites. Several spells in the Book of the Dead were intended to be spoken over specific amulets, which were then placed in particular places on the body of the deceased. Each Amulet had a specific meaning and symbolic significance, the most widely worn protective amulets
\end{abstract}

were: 1-the Horus eye life renewing ${ }^{\mathrm{ii}}$, the scarab beetle, was an image of God Khepri, the regenerated sun at dawn, it remained a powerful

image in magical texts, adapted for use as a seal ${ }^{\mathrm{iii}}$, 3-the life sign $a n x$, symbol of creative power ${ }^{\mathrm{iv}}$, according to the spell151 of the Book of the dead it was one of the four magical bricks need to be walled up in the funerary chamber towards the four cardinal points ${ }^{\mathrm{v}}$, the power of this symbol as an amulet may be derived entirely from its meaning :life,

4- the $\bigsqcup_{D d}$ pillar, symbol representing the building-up of the backbone and reconstruction of the body of God Osiris ${ }^{\mathrm{vi}}$, "it gives the power to reconstitute the body and become a perfect soul, symbolizing the Principle of Renewal ${ }^{\mathrm{vii}}$.

\section{Introduction}

The Ancient Egyptian words referring to an amulet were :( sA-wDAw-mkt) the word $s A$ Rdepicts a looped cord. The cord, which was usually of linen thread or leather, was always important and sometimes served as an amulet in itself.

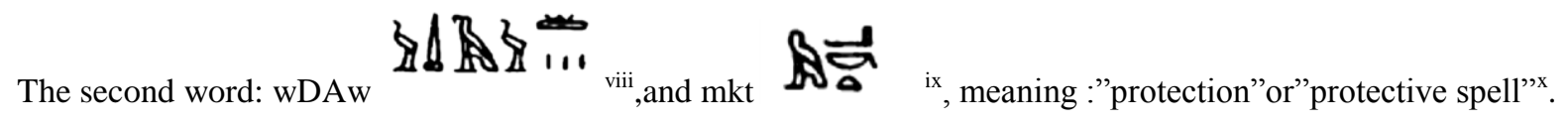

The Amulets in Ancient Egyptian thought were intended to restore to the mortal form the vital functions necessary for the journey through spiritual realms ${ }^{\mathrm{xi}}$. They were wrapped with the mummy to revitalize the organs of the body which the Egyptians deemed essential for protection in the afterlife ${ }^{\text {xii }}$, and were inscribed with words thought to ensure the fulfilment of the blessing expressed, or the granting of the bless desired ${ }^{\text {xiii }}$.The influence and potency of Amulets, and Talismans, was recognized in the religious services ,certain Amulets not only were worn during life, but were even attached to the dead body ${ }^{\mathrm{xiv}}$,not for a physical use but for magical benefits and magical protection ${ }^{\mathrm{xv}}$. They were among the main objects that the Ancient Egyptian Tombs were provided with ${ }^{\mathrm{xvi}}$, they have been recovered from houses , temples or shrines where votive offerings were made ${ }^{\text {xvii }}$, to ensure needs and desires of the deceased in his life after death which was in his beliefs a copy of his earthly life ${ }^{\text {xviii }}$.

Amulets occurred from the predynastic period throughout the Pharaonic era until the Greco-Roman period ${ }^{\mathrm{xix}}$.Petrie was the first to put 275 different kinds of Amulets under 5 classes, the first: Amulets of similars, the second :Amulets of power ,the third: Amulets of property ,the fourth: Amulets for protection and the fifth :Amulets of Gods ${ }^{\mathrm{xx}}$.Reisner classes Amulets N5218-6000 and 12001-12527 in catalogue of the Egyptian Museum ${ }^{\mathrm{xxi}}$.

Each Talisman and Amulet having a specified virtue, Petrie put the

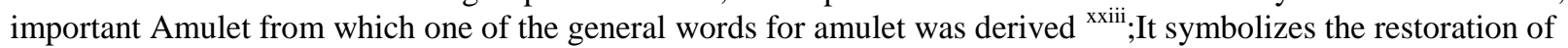


Horus's power, after his eye was torn away by Set ${ }^{\mathrm{xxiv}}$, as such, it represents the revitalization of the deceased, and numerous offerings were made in the name of the $w D A t$ to ensure the continuous process of vital restoration ${ }^{\mathrm{xxv}}$.Lexa added other classifications:1-natural objects,2-knots,3-demons and Gods,4-animals and parts of animals,5-parts of the human body,6-symbols,7-crowns and signs of rule,8-funerary ornaments and furniture ${ }^{\mathrm{xxvi}}$.

Some Amulets, like the two finger Amulets, were discussed but were not classed in 'Petrie' or 'Leska' classifications.

This paper aims to investigate some examples of those Amulets, to discuss their use and their significance in Ancient Egyptian thought.

\section{Types and uses of Amulets}

Amulets were of two types: some were inscribed with magical formulas, and were represented in magical papyri as vignettes in the religious literature ${ }^{\mathrm{xxvii}}$, the other type was without any magical formulas ${ }^{\mathrm{xxviii}}$.According to Bonner, the distinction between stones worn for the hope of securing divine protection for oneself, and others which invoke or seek to control powers, is not always clear. ${ }^{\text {xxix }}$ The technique of the religious amulets is much the same as that of the undoubtedly magical pieces, and they belong to the same period; a magical word or even a magical character would be enough to transfer a stone from one category to an other ${ }^{\mathrm{xx}}$.

There were two different uses of Amulets, the first use: the temporary amulets, were used on a temporary basis in crisis situations, probably always reinforced by magic spoken or written formulas; the second use: permanent amulets, were worn on a regular basis for permanent protection or benefit ${ }^{\mathrm{xxxi}}$.Some types of amulet were peculiar to the temporary category; others could serve as temporary or permanent, it is chiefly the permanent amulets that survive ${ }^{\mathrm{xxxii}}$. Some Egyptian amulets, particularly those worn as a temporary protection during a magical rite, consisted simply of the names of divine beings, these might be written on linen or papyrus or, in later times, on thin sheets of metal or the leaves of certain plants ${ }^{\text {xxiii }}$.

\section{Amulets and Spells:}

There were two main methods of harnessing the power of magic for defense against the sickness and harm: Amulet and spell $^{\text {xxxiv }}$.Beginning from the Middle kingdom these two elements were used in conjunction, Amulet inscribed with spells, were intended to provide its wearer with protection against any attacks ${ }^{\mathrm{xxxv}}$, and gave assurance that each part of the body would be kept healthy ${ }^{\text {xxxi }}$. The book of the dead contains spells of Amulets and spells which occur on Amulets $^{\text {xxxvii }}$, therefore they were anointed and empowered with spells ${ }^{\text {xxxviii }}$. Some magical spells were sometimes inscribed on Amulets ${ }^{\mathrm{xxix}}$, to form part of the protective power for the body. ${ }^{\mathrm{xl}}$ The head was regarded as a special part of the deceased's corpse to be protected and exalted in the funerary cult ${ }^{\text {xli }}$,spells151and 162 of the Book of the Dead, concerning the head, prescribe making an amulet depicting a cow, in order to generate the vital flame of the sun god at the head of the deceased ${ }^{\text {xlii }}$.

Due to the changes in religious practices and beliefs that prevailed during the New Kingdom ,mean people had a chance for an afterlife, therefore the protective amulets became more widely worn, mostly taking the shape of parts of the human body ${ }^{\text {xliii }}$. The standard explanation for Amulets taking this shape is that these amulets were to ensure the continued use of various limbs and organs in the afterlife ${ }^{\text {xliv }}$. Faith in the efficacy of those Amulets led to a sophisticated and decadent ritualism to a growing reliance on symbolism and magic ${ }^{x l v}$.Since many of these strings were worn in life, they may also have had a function in everyday magic; The fist, hand, heart, and finger amulets probably derive from magical protective gestures ${ }^{x l v i}$.

\section{Funerary-heart Amulet}

Heart Amulet was one of the most frequently depicted amulets in Ancient Egyptian art, being placed on the upper torso of the mummy ${ }^{\text {xlvii }}$,it was among the most important funerary amulets ${ }^{\text {xlviii }}$. The first depiction of this amulet was found during the $18^{\text {th }}$ Dynasty ${ }^{x l i x}$. The first documents that portray the use of heart amulets by non-royalty are found with the reign of King Amenhotep $\mathrm{II}^{1}$, as symbol of illuminated conscience ${ }^{\text {li }}$. They seem to have been used in earthly life as well as in the beyond, thus that acquire a significantly wide magical scope eii $^{\text {li }}$, they can provide protection to the rebirth that followed the weighing of the heart liii. Spell $30 \mathrm{~B}$ from the Book of the Dead urged the heart not to stand up as a witness against its owner during this trial, and this spell was often written on a heart scarab or on a heart-shaped amulet and placed on the chest of the mummy. ${ }^{\text {liv }}$

The human-headed heart Amulets blossom during the Ramesside Period and decrease afterwards ${ }^{\text {lv }}$, having a funerary purpose $^{\text {lvi }}$, they were sometimes used as an equivalent piece to the heart scarab ${ }^{\text {lvii }}$ providing the deceased with an assurance to be accepted in the eternal afterlife ${ }^{\text {lviii }}$. They were usually envisioned as a symbol of the newborn conscience of the deceased ${ }^{\text {lix }}$, unlike the heart amulets whose heads are pierced in order to suspend them, the humanheaded amulets do not have any pierce which would clearly indicate their funerary use ${ }^{\mathrm{lx}}$. The head is usually framed 
with a wig which attributes the deceased depicted as an Osirian divinity, sometimes carefully engraved with vertical lines to suggest the hair ${ }^{\text {lxi }}$. In some objects the wig is formed by the incrustation of a dark stone, while in some faience or glass amulets the hair can be colored with a black or dark blue pigment ${ }^{\text {lxii }}$.

\section{Case study}

Two cases study for unusual human- headed heart Amulets will be investigated, the first Amulet(Fig.1),is a rare find in an elaborate tomb of a scribe,discovered in Abydos ${ }^{\text {1xiii }}$, originally found in three pieces,the face is made of red jasper while the body is made of green jasper, and the wig of an unknown stone ${ }^{\text {Ixiv }}$.The second case (Fig.2)is one of the British Museum Amulets collection, it's a blue glazed Amulet with a red human face, and a striped black wig ${ }^{\text {lxv }}$.

The first case in Fig. 1 is a human-headed heart Amulet in red and green gasper ,characterized by a representation of:

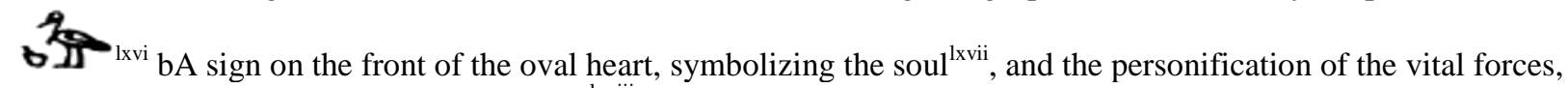
physical as well as psychic of the deceased ${ }^{1 \mathrm{lviii}}$. The Ba in Ancient Egyptian thought comes into existence at death, if the burial ritual and offerings have been properly accomplished for the deceased ${ }^{\text {Ixix }}$,so it can exercise a free movement in the realm of the afterlife ${ }^{\mathrm{lxx}}$. The heart was considered as a "seat" for the bA, representing the core and main aspect of the conscience $^{\text {lxxi }}$.
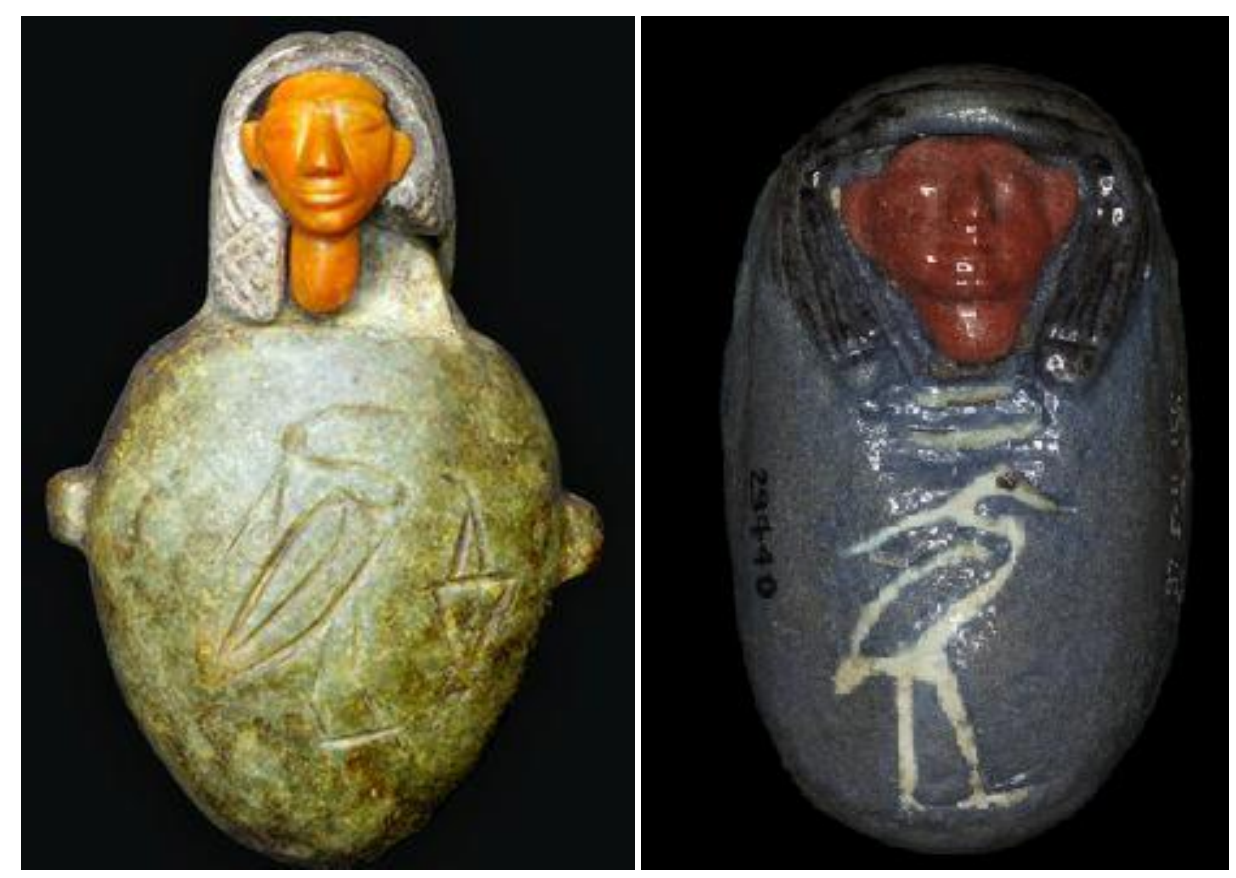

Fig.1 www.pinterest.com/unaturalsoul/egypt-5-art-2/last Fig.2 http://www.britishmuseum.org/

\begin{tabular}{|l|l|l|}
\hline Height & Fig.1 & Fig.2 \\
\hline Material & $6 \mathrm{~cm}$ & $1.74 \mathrm{~cm}$ \\
\hline Shape & -Red and green gasper. & $\begin{array}{l}\text {-Polychrome-Glazed } \\
\text { composition. }\end{array}$ \\
\hline Use & $\begin{array}{l}\text {-Human-headed heart amulet in } \\
\text { three pieces. } \\
\text {-A BA sign in the middle. }\end{array}$ & $\begin{array}{l}\text {-Human-headed heart Amulet } \\
\text { with the face inlaid. } \\
\text {-A Benu bird in the middle. }\end{array}$ \\
\hline
\end{tabular}




\begin{tabular}{|l|l|l|}
\hline Date & $-18^{\text {th }}$ Dynasty. & $18^{\text {th }}$ or $19^{\text {th }}$ Dynasty. \\
\hline
\end{tabular}

Table.1 Comparison between Fig 1and Fig 2.

The second case in Fig.2 is a polychrome-glazed composition human-headed heart Amulet with convex upper surface attached to a turquoise-green flat plaque, the head is inlaid separately ${ }^{\text {lxxii }}$.A benu bird symbol of the bA on the chest, representing the continual rebirth and regeneration; therefore it was an appropriate funerary symbol and the underside bears chapter30b of the Book of the dead in black glaze ${ }^{\text {lxxiii }}$.

Spells 83 and 84 of the Book of the Dead express the desire of the deceased to assume the form of a benu bird and thus to become identified with the sun god, and in the heart amulet spell 29 B he says: "I am the benu, the ba of Re".

Symbolism of Funerary Amulets: The role played by amulets in the tombs of the Late Period, however, is much greater than in earlier times, number and variety are greatly increased, due to a gradual development of Egyptian burial customs and some other influences ${ }^{\text {lxxiv }}$.Didier suggested that there were two main influences appeared to be of primary importance, one economic, the other religious, and these two influences go far to explain the growth in the part played by amulets in the funerary practices of the Ancient Egyptians ${ }^{\text {lxxv }}$. The faith in the efficacy of practical objects like Amulets, led to the growing reliance on symbolism and magic ${ }^{\text {lxxvi }}$. This tendency is reflected in the history of the country at this period, in the ever growing power of the priesthood ${ }^{\text {lxxvii }}$. Those priests were responsible of funeral practices, which were focused during this period on the mummy and its guiding through the paths of the underworld, by the host of texts of the Book of the dead, and magical protection provided by some Talismans and Amulets ${ }^{\text {lxxviii }}$.Spells and figures were drawn on narrow strips of papyrus to be rolled ,bound ,then placed in containers and be worn as Amulets during the Late Period ${ }^{\mathrm{lxxix}}$.

The range of funerary amulets increased greatly during the Late Period usually as a result of contemporary trends which led to the revival of forms not in use for hundreds of years or else as a result of democratization of funerary practices which made available to all amulets which earlier had been made exclusively for royal burials. Some funerary amulets were invented during the Late Period to supply a perceived lack; the obelisk amulets, and the "two-fingers" amulets, both belonging to the same group.

\section{The Obelisk Amulet}

Amulets in the shape of an obelisk were very rare. An obelisk amulet would allow assimilation with the sun and its daily renewal, a state which was greatly desired by the dead ${ }^{1 \mathrm{xxx}}$. Although the obelisk with its solar symbolism had played an integral role in religious architecture since the Old Kingdom, Amulets in the form of an obelisk do not occur before the Late Period ${ }^{\mathrm{lxxxi}}$.According to Andrews, its appearance may be connected with the contemporary revival of the Old Kingdom practice of flanking the doors to private tombs with small soft stone obelisks: the vignettes of the Late Period funerary papyri depicting the last rites at the tomb show a pair of small obelisks as the goal of the funeral procession $^{\text {lxxii }}$.

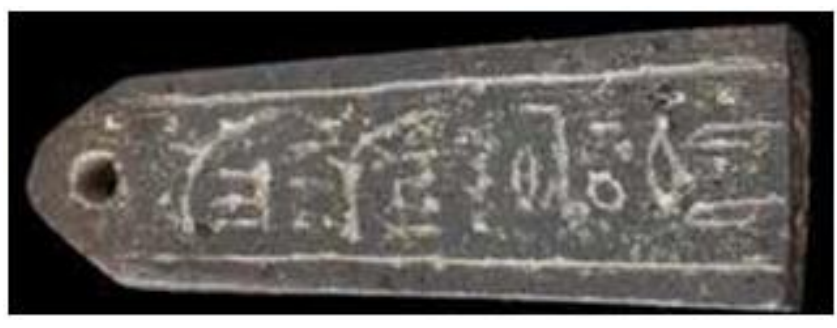

Fig.3: An unusual steatite amulet in the form of an obelisk inscribed with the name and titles of its owner,height:3.8cm : www.PalArch.nl

The inscription carved down the front of the shaft :imy r SA kAmw, according to Wilson translation: "Overseer of the vines" or "Overseer of the vineyard"lxxxiii.

\section{The Two fingers Amulet}

The Symbolism The 'two-finger' amulet shows the index and middle fingers, with the nails and joints clearly indicated, it was symbolical of help, assistance, and benediction, typified by the two fingers extended by Horus to assist his father in mounting the ladder suspended between this world and the netherworld ${ }^{\text {lxxiv }}$. Also the fingers were ever considered an emblem of Strength and Power, the raising of the first two fingers being regarded as a sign of Peace and Good Faith ; the first finger being the indicator of divine will and justice and the only one that can stand erect by itself alone ; the second representing the Holy Spirit, the Mediator ${ }^{\text {lxxxv }}$. The symbolism of extending the index and middle two fingers is still used today as a sign of ecclesiastical benediction ${ }^{\text {lxxxvi }}$, also it is a modern sign for victory. 
Place on the mummy It was placed on the mummy near the incision by which the internal organs were removed before embalming, therefore it was frequently placed in the interior of the mummified body to enable him to travel to the regions of heaven ${ }^{1 \times x x v i i}$. This may suggest that the amulet was intended to reaffirm the embalming process, the fingers representing those of Anubis, the god of embalming ${ }^{\text {lxxviiii }}$. However, the amulet could also have been intended to hold the incision sealed, to prevent malign forces from entering the body, like the plaques sometimes placed over the wound ${ }^{1 \mathrm{lxxix}}$.

Material and color The 'Two-finger' amulets were mostly made of a dark hard stone such as basalt, obsidian ${ }^{\mathrm{xc}}$ or steatite. Black was associated with the Underworld ${ }^{\mathrm{xci}}$. Black stones were often used to make statues of Osiris and for sarcophagi and other objects which were to be placed inside tombs ${ }^{x \mathrm{xii}}$. The hardness of the stones was symbolic of endurance; amulets were made of such materials to ensure that their magical powers lasted for all eternity. This is consistent with both interpretations of the function of the 'two-finger' amulet, as it was important that the body remained intact forever, so that the deceased could enjoy the Afterlife ${ }^{\text {xiii }}$.

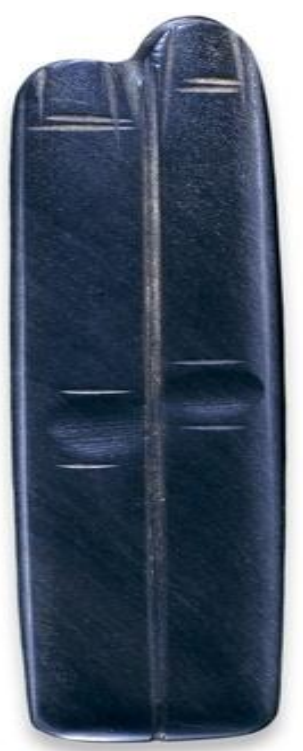

Fig.4www.britishmuseum.org/obsidianamulet,last online/search/545365

Case study we have two cases for the 'Two-finger' amulets, the first is one of the British Museum's collection (Fig.4), and the second is one of the collection of the Metropolitan museum of Art gallery (Fig.5);both dating to the late Period, this type of Amulet was a late arrival, first evident only after around $600 \mathrm{BC}^{\mathrm{xciv}}$.

\begin{tabular}{|l|l|l|}
\hline & Fig.4 & Fig.5 \\
\hline & $\begin{array}{l}\text { Length: } 8.520 \mathrm{~cm} \\
\text { Width: } 2.170 \mathrm{~cm}\end{array}$ & $\begin{array}{l}\text { Length: } 8.8 \mathrm{~cm} \\
\text { Width: } 2.8 \mathrm{~cm}\end{array}$ \\
\hline Date & After 600B.C & 664B.C \\
\hline Material & Obsidian black stone & Dark stone \\
\hline Symbolism & $\begin{array}{l}\text {-Protective Amulet to evoke the } \\
\text { regenerative qualities of Osiris } \\
\text { and the Underworld. }\end{array}$ & $\begin{array}{l}\text {-Protective talisman symbolizing the } \\
\text { prayers made requesting help, } \\
\text { assistance, approval and blessing. }\end{array}$ \\
\hline
\end{tabular}




\begin{tabular}{|l|l|l|}
\hline Shape & $\begin{array}{l}\text { The two fingers are separated, } \\
\text { the first is the indicator of justice } \\
\text { the second finger represents the } \\
\text { spirit, perhaps referring to } \\
\text { Anubis God of embalming. }\end{array}$ & $\begin{array}{l}\text { The two fingers are linked to indicate } \\
\text { strength and power, perhaps referring } \\
\text { to Horus, who helped Osiris to ascend } \\
\text { to the sky. }\end{array}$ \\
\hline
\end{tabular}

Table.1 Comparison between Fig 4and Fig 5

\section{Unusual Magical Amulets}

Amulets were sometimes named magical stones due to their role ${ }^{\mathrm{xcv}}$, some of those amulets were used in magic in purpose of protection for the deceased, like turtle and scorpion Amulets.

The turtle was named StA or Stw:' the mysterious one', the turtle Amulet was often invoked in magic ${ }^{\text {xcvi }}$,it intended to represent a creature of evil symbolizing death and darkness ${ }^{\text {xcvii }}$, probably due to its water-based existence, it was believed to inhabit the murky waters of the Underworld, waiting to impede the nightly progression of the Sun God's bark $^{\text {xcviii }}$.By the New Kingdom the sun god's hostility toward the umbrageous turtle was even more strongly formulated

in the phrase, "

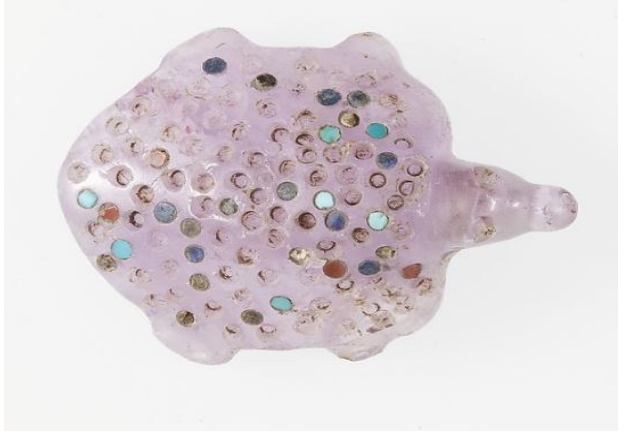

Fig.6 Middle KingdomTurtle Amulet in Rock crystal inlaid with amethyst, turquoise, lapis-lazuli, and red jasper-height:1.6 cm http://www.metmuseum.org/collection/the-collection-online/search/544102

May Re live and may the turtle die" ${ }^{\text {xcix }}$.

Middle Kingdom coffin text shows a spell protecting the deceased against the distressing possibility of having to eat excrement in the next world:"If you tell me to eat this, then Re will eat turtle"c. It must have been, more specifically, the shadowy and secretive existence of the turtle that brought it into opposition with the powerful sun god, who was obliged to pass beneath its dark domain his nightly journey ${ }^{\mathrm{ci}}$. Turtle amulets are often made in amethyst ${ }^{\mathrm{cii}}$, they were figured prominently in early Egyptian art and were used for medicinal purposes during the Middle Kingdom, although never taken internally ${ }^{\text {ciii }}$. The turtle may have seemed to possess a dual character, being an animal of the shadowy deep, it embodied cosmic danger and was ritually annihilated, but its power could also be made to work to the advantage of people by warding off evil, this power made turtles a very potent Amulets ${ }^{\text {civ }}$.

Scorpion amulets refer to Goddess Selqet or Serket ,according to her name:srot, which means:' 'she who causes (one) to breath $^{\text {'cv }}$. She was the Goddess who helped kings and Gods to be born and was one of the four Goddesses who traditionally protected the embalmed bodies of the dead ${ }^{\text {cvi }}$.Scorpions were occasionally painted as funerary motifs on cartonnage mummy cases ${ }^{\text {cvii }}$, the depiction of scorpions were at the top of the head ${ }^{\text {cviii }}$. A scorpion amulet might be either the goddess Serqet, or simply an image of a venomous insect used to repel danger ${ }^{\mathrm{cix}}$, used for protection ${ }^{\mathrm{cx}}$, and in medical magic, they were placed around the neck of patients who had been stung ${ }^{\text {cxi }}$. The scorpion may protect a child against real scorpions $^{\text {cxii }}$, or may represent Goddess Serqet who helps the Divine Mother and her child in magical texts $^{\text {cxiii }}$. Having a relationship to God Set in his role as devourer or divider ${ }^{\text {cxiv }}$, Scorpions were displayed on Scarab seals (Fig.7)as a sign of protection against dangerous animals ${ }^{\mathrm{cxv}}$. 

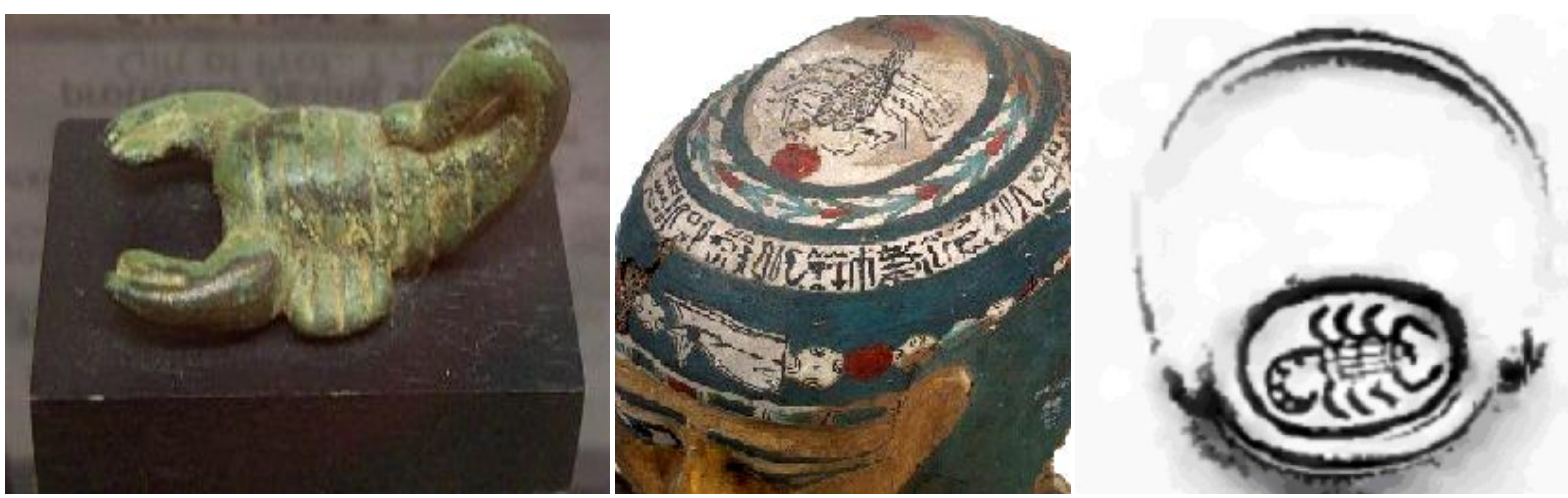

Fig.7:From left to right: scorpion Amulet in Manchester Museum: https://egyptmanchester.wordpress.com/2008/06/20/-

Scorpion painting the head of a mask: Miatello.L(2012),Ptolemaic Mummy Masks with Spells from the Book of the dead concerning the head,JSSEA,vol.39, p.85/A scorpion seal :Sparavigna.A(2009),Ancient Egyptian seals and Scarabs, Torino,p.24.

\section{Conclusion}

Amulets deemed essential for protection, so they were worn to grant the deceased an access to the secret places in the afterlife, also they granted to the living the ability and power which protect him from evil forces. The number of amulet types definitely based on the iconography of Egyptian gods increased. When we consider the long process of evolution out of which the amulets were developed, and when we realize the multiplicity of Gods and the variety of beliefs in different parts of the country and at different periods through Ancient Egyptian history, we find great difficulty in defining the meaning and the particular potency of each single Amulet. Some we know to have been originally connected with primitive animal worship and later to have become associated with to a particular God to whom that animal becomes sacred; Others take the form of natural objects and are to be thought of as representing those things buried with dead for particular purposes, while still others in the form of hieroglyphic signs seem to be intended to ensure to the dead the qualities inherent in the ideas for which those signs stand.

This paper investigated some distinguished and unusual Amulets who were used in purpose of temporarily or permanently protection. The obelisk amulet was used to allow assimilation with the sun and its daily renewal, a state which was greatly desired by the dead. The Human-headed heart Amulets were characterized with the benu bird symbol of the bA on the chest, representing the continual rebirth and regeneration, who were essential for the deceased. The 'two-fingers 'Amulets were considered an emblem of Strength and Power, the raising of the first two fingers being regarded as a sign of Peace and Good Faith, while symbolism of extending the index and middle two fingers is still used today as a sign of ecclesiastical benediction, also it is a modern sign for victory. Turtle and Scorpion Amulets were used in magic in purpose of protection for the deceased. So we can conclude that Amulets had mainly funerary purpose for protection, the full range of amulet jewellery is not in fact shown in painting or relief at any period. Art of tombs and temples in Ancient Egypt was intended to evoke a perfect world in which there would be none of the crises or terrors that required the use of amulets.

\section{بعض التمائم المميزة في الفن المصري القديم.}

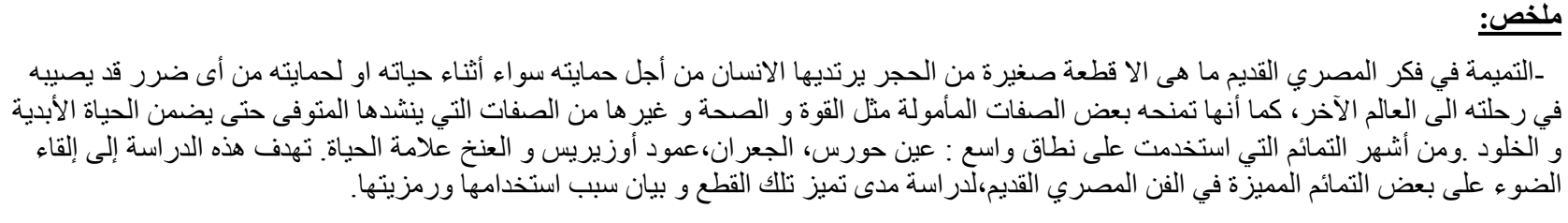

\section{Refrences:}

1. -Andrews.C(1994)Amulets of Ancient Egypt, British Museum press, London.

2. -Andrews.C(2004), An unusual inscribed amulet,PalArch.nl, archaeology of Egypt/Egyptology: (Netherlands scientific journal).

3. -Arnold.D(1995), An Egyptian Bestiary ,Bulletin of the Metropolitan Museum of Art,Spring1995.

4. -Bonner.C(1950), Amulets chiefly in the British Museum a supplementary article,Mitchigan University. 
5. -Borghouts.J(1978),Ancient Egyptian Magical Texts, Religious Texts translation series,Nisaba,vol.9,Leiden.

6. -Clark.R(2000), The Sacred Tradition in Ancient Egypt,Minnesota.

7. -Cooney.K,Tyrrell.J(2005),Scarabs in the Los Angeles county Museum of Art,California.

8. -Dunham.D(1930),Amulets of the Late Period ,BMFA:Bulletin of the Museum of Fine Arts,Boston,vol.28.

9. -Edwards.I(1980),Krankheitsabwehr,LÄ(III).

10. -Faulkner.R(1962),A Concise Dictionary of Middle Egyptian,Oxford.

11. -Fisher.H (1966),Egyptian Turtles,Bulletin of The Metropolitan Museum of Art,vol.24.

12. -Ford.M(2013),Necrominon Egyptian Sethanic Magick,Houston.

13. -Frembgen.J(2000), The scorpion in Muslim folklore,Munich.

14. -Garfield.E(1986), The Turtle: A Most Ancient Mystery. Part 1. Its Role in Art, Literature, and Mythology, Essays of an Information Scientist, Vol:9.

15. -Hackley.L(2014),Amethyst,Apotropala,and the eye of $\operatorname{Re}, A$ Thesis submitted to the department of The Sociology, Anthropology, Psychology, and Egyptology, The American University in Cairo,p.11.

16. -Harris.E,Ancient Egyptian Divination and Magic,Boston.

17. -Hayes.W(1964), The Scepter of Egypt,part,New York. -Kristiky.G,Cherry.R(2000),Insect Mythology,Lincoln.

18. -Känel.F(1984),Selqet,LÄ(V).

19. -Klasens.A(1975),Amulet,LÄ(II),Wiesbaden.

20. -Lexa.F(1927),La magie dans l'Egypte Antique de l'Ancien Empire jusqu'a l'époque Copte ,Isis ,vol.9 No.3.

21. -Miatello.L(2012),Ptolemaic Mummy Masks with Spells from the Book of the dead concerning the head,JSSEA:Journal of the society for the study of the Egyptian Antiquities,vol.39.

22. -Petrie.F(1914),Amulets ,London.

23. -Pinch.G(1994),Magic in Ancient Egypt,London.

24. -Régen.I(2010), When the Book of the Dead does not match archaeology: The case of the protective magical bricks (BD 151),BMSA:British Museum Studies in Ancient Egypt and Sudan,vol.15.

25. -Reisner.M(1907),Amulets, Catalogue Général Des Antiquités Egyptiennes du Musée duCaire,Le Caire.

26. -Sarr.J(2004), Gayer-Anderson Scarab collection in Portland art museum,Portland ,OregonUSA.

27. -Sousa.R(2007), The Heart Amulet in Ancient Egypt: A Typological study, Proceedings of the ninth international congress of Egyptologists, Leuven.

28. -Sousa.R(2007), The meaning of the heart amulets in Egyptian art, JARCE :Journal of the American Research Center in Egypt(43).

29. -Sousa.R(2008), Animal and Human Headed Heart Amulets: Symbolism and Meaning, BSÉG 28.

30. -Sousa.R,(2010) Symbolism and Meaning of the Cornice Heart amulets ,CdE:Chronique d'Egypte (75).

31. -Sparavigna.A(2009),Ancient Egyptian seals and Scarabs, Torino.

32. -Thomas.W,Pavitt.K(1922), The Book of Talismans ,Amulets and Zodiacal gems, $2^{\text {nd }}$ edition, London.

33. -Wilkinson.T, The rise and fall of Ancient Egypt,London2010.

34. -Žabkar.L(1975),Ba, ,LÄ(II),Wiesbaden.

مر اجع عبر شبكة الانترنت

-Budge.W, Egyptian magic: http://www.golden-dawn-canada.com/pdf/egyptian\%20magic.pdf.

Last updated23/12/2014.

-Erman.A,Grapow.H (1971)Wörterbuch der aegyptischen Sprache,Berlin,band I,p.401,last updated 13/12/2014. 
-Erman A., Grapow H. Wörterbuch der aegyptischen Sprache Bd. I-V (1926-1931), VI (1950), VII (1971),Belegstellen $\underline{\mathrm{I}-\mathrm{V}}, \mathrm{Wb}(\mathrm{I}), \mathrm{p} .411$.

-http://www.jacobusvandijk.nl/docs/OfE_130-131.pdf,p.131.

www.britishmuseum.org/research/collection_online/collection_object details.aspx?objectId=143689\&partId=1\&search $\underline{\text { Text=Egyptian+amulets } \& \text { page }=3}$

-www.pinterest.com/unaturalsoul/egypt-5-art-2/last updated:13/12/2014.

-www.britishmuseum.org/obsidianamulet,last updated:12/12/2014.

'-Cooney.K,Tyrrell.J(2005),Scarabs in the Los Angeles county Museum of Art,California,p.3.

ii -Kristiky.G,Cherry.R(2000), Insect Mythology,Lincoln, p.20.

iii -Sparavigna.A(2009),Ancient Egyptian seals and Scarabs,Torino, p.9.

iv -Thomas.W,Pavitt.K(1922), The Book of Talismans, Amulets and Zodiacal gems, $2^{\text {nd }}$ edition, London, p.61.

$\checkmark$-Régen.I(2010), When the Book of the Dead does not match archaeology: The case of the protective magical bricks (BD 151),BMSA:British Museum Studies in Ancient Egypt and Sudan,vol.15,p.268.

vi - Thomas,Pavitt.,op.cit,p.64.

vii-Clark.R(2000), The Sacred Tradition in Ancient Egypt,Minnesota,p.94.

viii -Erman.A,Grapow.H (1971)Wörterbuch der aegyptischen Sprache, Berlin, band I,p.401,last updated 13/12/2014.

ix -lbid,Bandll, p.162.

- Faulkner.R(1962),A Concise Dictionary of Middle Egyptian,Oxford,p.119.

${ }^{x}$-Ibid.

xi- Clark,op.cit,p.315.

xii -lbid.

xiii -Hayes.W(1964), The Scepter of Egypt,part1,New York,p.82.

xiv-Thomas,Pavitt.K,op.cit,P.59.

${ }^{x v}$-Petrie.F(1914),Amulets, London, p.5.

xvi-Dunham..D(1930),Amulets of the Late Period ,BMFA:Bulletin of the Museum of Fine Arts,Boston,vol.28, ,p.117.

xvii -Pinch.G(1994),Magic in Ancient Egypt,London, p.105.

xviii - Ibid.

xix -Klasens.A(1975),Amulet,LÄ(II),Wiesbaden,col.233.

${ }^{x x}$-lbid.

xxi -Reisner.M(1907),Amulets, Catalogue Général Des Antiquités Egyptiennes du Musée duCaire,Le Caire.

xxii Erman.A,Grapow.H,op.cit,p.401.

xxiii -Pinch,op.cit,p.109.

${ }^{x x i v}$-Clark,op.cit,p.315.

${ }^{x \times v}$-lbid.

xxvi-Klasens,op.cit,col.233.

xxvii -lbid.

xxviii -Budge.W, Egyptian magic: http://www.golden-dawn-canada.com/pdf/egyptian\%20magic.pdf. Last updated23/12/2014.

xxix -Bonner.C(1950), Amulets chiefly in the British Museum a supplementary article,Mitchigan

University,p.302

${ }^{x \times x}$-Ibid.

xxxi -Pinch,op.cit,p.105.

xxxii -Ibid.

xxxiii - Ibid,p.111.

${ }^{x x x i v}$-Edwards.I(1980),Krankheitsabwehr, L̈̈(III),col760.

${ }^{x \times x v}-$ Ibid,col.761.

xxxvi -lbid.

xxxvii -BD19, BD29B,BD155,BD156,BD157mBD158,BD159,BD166, BD6,BD30B.

xxvviii - Clark,op.cit,p.315.

${ }^{x x x i x}$-lbid. 
$x \mathrm{l}$-lbid.

xli -Miatello.L(2012),Ptolemaic Mummy Masks with Spells from the Book of the dead concerning the head,JSSEA:Journal of the society for the study of the Egyptian Antiquities,vol.39, p.39.

xlii -lbid,p.53.

xliii -Pinch.G,op.cit,p.113.

xliv -Ibid.

xlv - Dunham,Amulets of the late periodmop.cit,p.122.

xlvi -Pinch.G,op.cit,p.113.

xlvii -Sparavigna,op.cit, p.22.

xlviii http://www.jacobusvandijk.nl/docs/OfE 130-131.pdf,p.131.

${ }^{x}$ lix Sousa.R(2007), The meaning of the heart amulets in Egyptian art, JARCE :Journal of the American Research Center in Egypt(43), p.59.

I -Ibid,p.60.

li -lbid,p.63.

lii -Sousa.R,(2010) Symbolism and Meaning of the Cornice Heart amulets,CdE:Chronique d'Egypte,.(75),p.90.

liii -lbid,p.91.

${ }^{\text {liv }}$ http://www.jacobusvandijk.nl/docs/OfE 130-131.pdf,p.131.

Iv -Sousa.R(2008), Animal and Human Headed Heart Amulets: Symbolism and Meaning, BSÉG 28,p.130.

Ivi -Sousa.R(2007), The Heart Amulet in Ancient Egypt: A Typological study, Proceedings of the ninth international congress of Egyptologists, Leuven,p.717.

Ivii -Ibid.

Iviii -Sarr.J(2004),Gayer-Anderson Scarab collection in Portland art museum,Portland ,OregonUSA, p.41.

lix -Sousa(2007),op.cit,717.

Ix -Sousa(2008),op.cit, p.130.

Ixi -lbid.

Ixii -lbid.

Ixiii www.pinterest.com/unaturalsoul/egypt-5-art-2/last updated:13/12/2014.

Ixiv -Ibid.

${ }^{1 x v}$ www.britishmuseum.org/research/collection_online/collection_object_details.aspx?objectId=143689\&partId=1\&sear $\underline{\text { chText=Egyptian+amulets\&page }=3}$

Ixvi Erman A., Grapow H. Wörterbuch der aegyptischen Sprache Bd. I-V (1926-1931), VI (1950), VII (1971), Belegstellen $\mathrm{I}-\mathrm{V}, \mathrm{Wb}(\mathrm{I}), \mathrm{p} .411$.

Ixvii-Žabkar.L(1975),Ba, ,LÄ(II),Wiesbaden,col.588.

Ixviii -Ibid,col.589.

Ixix -lbid.

Ixx -Ibid.

Ixxi -Ford.M(2013),Necrominon Egyptian Sethanic Magick,Houston,p.96.

Ixxii -Andrews,Amulets,op.cit,p.65.

Ixxiii -Ibid.

Ixxiv - Dunham,op.cit,p.117.

Ixxv -Ibid, p.121.

Ixxvi -lbid.

Ixxvii -Wilkinson.T, The rise and fall of Ancient Egypt,London2010,p.245.

Ixxviii - Dunham,op.cit,p.121.

Ixxix -Klasens,op.cit,col.234.

Ixxx -Andrews.C(2004), An unusual inscribed amulet,PalArch.nl, archaeology of Egypt/Egyptology: (Netherlands scientific journal), 1, 2 ,p.18.

Ixxxi -lbid.

Ixxxii -Ibid.

Ixxxiii -Ibid, p.19.

Ixxxiv - Thomas.W,Pavitt.K,op.cit,p.70.

Ixxxv -Ibid.

Ixxxvi - Dunham,op.cit,p.122.

Ixxxvii -lbid. 
Ixxxviii -www.britishmuseum.org/obsidianamulet,last updated:12/12/2014.

Ixxxix -Ibid.

${ }^{x c}$-Volcanic stone ,black or dark olive: Reisner.G.A(1907),Amuletsl, CG:Catalogue Génerale des Antiquités Egyptiennes du Musée du Caire(5218-6000et12001-12527),Le Caire ,p.129.

xci-Thomas.W,Pavitt.K,op.cit,p.70.

xcii -Ibid.

xciii-lbid.

xciv -Andrews.C(1994)Amulets of Ancient Egypt, British Museum press,London,p.70.

xcv -Borghouts.J(1978),Ancient Egyptian Magical Texts, Religious Texts translation series,Nisaba,vol.9,Leiden,p.

xcvi - Pinch, Magic in Ancient Egypt,op.cit,p.42.

xcvii -Andrews,op.cit,p.36.

xcviii -lbid.

xcix -Fisher.H (1966), Egyptian Turtles, Bulletin of The Metropolitan Museum of Art,vol.24,p.195.

c -lbid.

ci -lbid.

cii -Hackley.L(2014),Amethyst,Apotropala, and the eye of Re ,A Thesis submitted to the department of The Sociology, Anthropology, Psychology, and Egyptology, The American University in Cairo,p.11.

ciii -Garfield.E(1986), The Turtle: A Most Ancient Mystery. Part 1. Its Role in Art, Literature, and Mythology, Essays of an Information Scientist, Vol:9, p.294.

civ -Arnold.D(1995), An Egyptian Bestiary ,Bulletin of the Metropolitan Museum of Art,Spring1995,p.34.

cv -Känel.F(1984), Selqet,LÄ(V),col.831.

cvi -Pinch,Magic in Ancient Egypt,op.cit,p.36.

cvii -Frembgen.J(2000), The scorpion in Muslim folklore,Munich,p.99.

cviii Miatello,op.cit,p.69.

cix -Pinch,op.cit,p.113.

cx -Sparavigna,op.cit, p.31.

cxi -Harris.E,Ancient Egyptian Divination and Magic,Boston,p.84.

cxii-Lexa.F(1927),La magie dans l’Egypte Antique de l'Ancien Empire jusqu'a l'époque Copte ,Isis ,vol.9 No.3,p.105.

cxiii-Pinch,op.cit ,p.116.

cxiv - Clark,op.cit,p.95.

${ }^{c x v}$-Sparavigna,op.cit, p.32. 